\title{
Hidrogén tárolása homogén katalitikus kémiai rendszerekben
}

\author{
JOÓ Ferenc, ${ }^{a}{ }^{*}$ PAPP Gábor, ${ }^{a}$ HORVÁTH Henrietta ${ }^{b}$ és KATHÓ Ágnes ${ }^{a}$ \\ ${ }^{a}$ Debreceni Egyetem, Fizikai Kémiai Tanszék, Egyetem tér 1.,4032 Debrecen, Magyarország \\ ${ }^{b}$ MTA-DE Redoxi- és Homogén Katalitikus Reakciók Mechanizmusa Kutatócsoport, \\ Egyetem tér 1., 4032 Debrecen, Magyarország
}

\section{Bevezetés}

A földi légkörben található szén-dioxid -üvegház hatása miattjelentős mértékben hozzájárul a globális felmelegedéshez. Koncentrációja jelenleg már meghaladja a korábban kritikusként emlegetett 400 ppm értéket ${ }^{1}$. Az atmoszférába jutó szén-dioxid jelentős hányada fosszilis eredetü folyékony motorhajtó anyagok elégetéséből származik. A légköri $\mathrm{CO}_{2}$ felhalmozódás lassításának egyik módja a megújuló forrásból származó üzemanyagok használata. E megállapítással természetesen nem kívánjuk csökkenteni a más területeken -pl. cementgyártás, fosszilis energiahordozók nem üzemanyagként történő elégetése- elérhető eredmények értékét. Minden olyan technológiai folyamat és közlekedési, energetikai fejlesztés, ami hozzájárul a légköri szén-dioxid konentráció csökkentéséhez (vagy legalább a kibocsátás mérsékléséhez), rendkivül fontos szereppel bír a klímaváltozás hatásainak enyhítésében.

Világszerte kiterjedt kutatás és fejlesztés folyik a megújuló energiák hasznosítása, a segítségükkel nyerhető nem szén vagy kőolaj alapú üzemanyagok előállítása és felhasználása céljával. A benzin és a gázolaj helyettesítésére számos anyagféleséget javasoltak már, közülük most csak a hidrogént, $^{2}$ a metanolt ${ }^{3}$ és a $\gamma$-valerolaktont ${ }^{4}$ említjük. Mindhárom alternatív üzemanyagnak vannak előnyös és hátrányos fizikai és kémiai tulajdonságai, ezeket itt nem részletezzük. Egyedül arra utalunk, hogy míg a metanol és a $\gamma$-valerolakton közönséges körülmények között folyadék halmazállapotú, így a jelenlegi motorhajtó anyagokhoz hasonlóan tárolható ill. szállítható, addig a $\mathrm{H}_{2}-252,88^{\circ} \mathrm{C}$ hőmérséklet felett gáz, aminek tárolására és járművek fedélzetén történő szállítására különleges módszereket kell alkalmazni. $^{5}$ Minthogy azonban a hidrogén oxidációja tüzelőanyag cellákban közvetlenül elektromos energiát szolgáltat (miközben a környezetre ártalmatlan víz keletkezik), továbbra is nagy érdeklődést vált ki a $\mathrm{H}_{2}$ tárolása, akár mobil, akár helyhez kötött eszközök energia ellátása érdekében.

A hidrogén tárolásának egyik lehetséges módja, ha azt megfelelő módon egy olyan vegyületbe építjük be (hidrogénezés), amelyből a szükségletnek megfelelő időben és sebességgel $\mathrm{H}_{2}$ gázt lehet felszabadítani (dehidrogénezés). A hidrogénezés és dehidrogénezés az esetek túlnyomó többségében csak katalizátorok hatására játszódik le. Egyszerüsíti a helyzetet ha mind a hidrogénezést, mind a $\mathrm{H}_{2}$ felszabadítást ugyanazzal a katalizátorral, ugyanabban az edényben végezhetjük, a körülmények (elsősorban a $\mathrm{H}_{2}$ nyomás és/vagy a hőmérséklet) változtatásával. Ez esetben beszélhetünk $\mathrm{H}_{2}$-akkumulátorról, melynek töltése (hidrogénezés) és kisütése (dehidrogénezés) az elektromos akkumulátorok működésével analóg folyamat. A következőkben bemutatjuk kutatócsoportunk eredményeit a $\mathrm{H}_{2}$-akkumulátorok megalkotásában valamint azoknak a kémiai folyamatoknak a vizsgálatában, melyek alkalmasak lehetnek ilyen akkumulátorok létrehozására. Ezzel egyben tisztelegni kívánunk Oláh György emléke előtt, aki ezeken a területeken is rendkívül fontos eredményeket ért el.

\section{Oláh György munkásságának néhány kiemelkedő eredménye az alternatív motorhajtó anyagok valamint a hidrogén tárolása terén}

Oláh György energetikai vonatkozású munkásságából talán a leginkább ismert eredmény az un. metanol gazdaság koncepciója ${ }^{5,6,7}$. E javaslat szerint a metanol lehetne az az un. platform vegyület, amelynek bázisán az ipar a jelenleg fosszilis szénhidrogén alapon elöállított vegyületek, anyagféleségek sokaságát gyártaná. Ugyancsak a metanol lehetne a legszélesebb körben használt motorhajtó anyag, ideális esetben közvetlenül metanollal müködő tüzelőanyag elemben ${ }^{8}$ oxidálva vízzé és szén-dioxiddá. Ha a metanolt légköri szén-dioxid hidrogénezésével állítják elő (1. egyenlet), aminek üzemanyagként történő elégetése során ekvimoláris mennyiségü $\mathrm{CO}_{2}$ keletkezik, akkor a körfolyamat révén formálisan nem kerül többlet szén-dioxid a levegőbe.

$$
\mathrm{CO}_{2}+3 \mathrm{H}_{2} \rightarrow \mathrm{CH}_{3} \mathrm{OH}+\mathrm{H}_{2} \mathrm{O}
$$

Az elképzelés szélesebb körü valósággá válását több tényező hátráltatja. Bár a szén-dioxid heterogén katalitikus közvetlen hidrogénezése metanollá technikailag megoldott, a metanol ipari előállítása jelenleg nem $\mathrm{CO}_{2}$, hanem fosszilis forrású szintézis gáz alapon történik. Ugyanakkor a metanol tüzelöanyag elemek jelenleg még nem alkalmasak arra, hogy a közlekedésben általánosan átvegyék az elektromos meghajtású gépjárművek áramforrásának szerepét. Nem hagyható figyelmen kívül az sem, hogy a metanol erősen mérgező, és mivel vízzel elegyedik könnyen bekerülhet a környezetbe is. Ahhoz, hogy a $\mathrm{CO}_{2}$ hidrogénezésén alapuló metanol előállítás gazdaságos lehessen olcsó hidrogénre van szükség, amit elvileg a megújuló energiaféleségek (szél- és napenergia, stb.) felhasználásával lehet nyerni - e téren

*Tel.: +36-52-512-900; fax: +36-52-512-915; e-mail: joo.ferenc@science.unideb.hu 
azonban még sok a teendő. Mindezen akadályozó tényezők ellenére az izlandi Reykjanes-ben 2012-ben megkezdte működését az Oláh Györgyről elnevezett metanol üzem, légköri $\mathrm{CO}_{2}$ és helyben elérhető, olcsó geotermikus energia felhasználásával ${ }^{9}$.

A hidrogén tárolásának ígéretes és intenzíven vizsgált anyaga a hangyasav. A hangyasav közönséges körülmények között könnyen tárolható és szállítható, nem mérgező folyadék, melynek bomlása hidrogént (és $\mathrm{CO}_{2}$-t) eredményez (2. egyenlet).

$$
\mathrm{HCO}_{2} \mathrm{H} \rightarrow \mathrm{H}_{2}+\mathrm{CO}_{2}
$$

A folyamat homogén ${ }^{10,11,12}$ és heterogén ${ }^{13,14}$ katalizátorok hatására egyaránt végbemegy. A képződő $\mathrm{H}_{2}$-t motorhajtásra is használhatják hidrogén üzemanyag cellák alkalmazásával - utóbbiak már technikailag érett, stabilis konstrukciók. Fontos feltétel azonban, hogy a (2) folyamat mellékreakciójaként ne menjen végbe a hangyasav dehidratálása, ami az üzemanyag elem elektródjait mérgező szén-monoxidot eredményez (3. egyenlet).

$$
\mathrm{HCO}_{2} \mathrm{H} \rightarrow \mathrm{H}_{2} \mathrm{O}+\mathrm{CO}
$$

Atomgazdaságosság szempontjából a $\mathrm{CO}_{2}$ hangyasavvá történő hidrogénezése, azaz a (2) folyamat fordítottja kedvezőbb, mint a metanol (1) szerinti szintézise, mert nem kíséri vízképződés, ami az értékes $\mathrm{H}_{2}$ egy részének elvesztéséhez vezet. Gyakorlatilag azonban a $\mathrm{CO}_{2}$ hangyasavvá történő hidrogénezése adalékanyagok (aminok, amino-alkoholok, egyéb bázisok) nélkül csak lassan és kis konverzióval játszódik le. Ez magyarázza, hogy a kutatások túlnyomó részében a hangyasavat, mint nagy volumenü ipari terméket adottnak tekintik és a dehidrogénezés (bontás) katalízisére koncentrálnak.

Oláh György és munkatársai kiemelkedő eredményeket értek el a hangyasav bontás katalízisében $\mathrm{IrCl}_{3}$-ból és különféle N-tartalmú ligadumokból in situ előállított katalizátorok alkalmazásával ${ }^{15}$ (1. ábra).

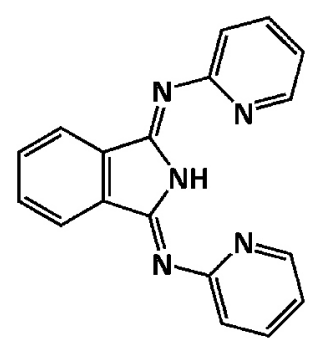

1

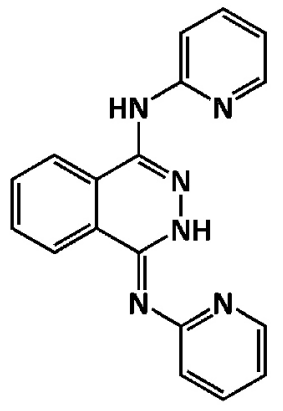

2
1. Ábra. Oláh György és munkatársai által hangyasav bontásához szintetizált iridium-alapú katalizátorok ligandumai ${ }^{15}$.

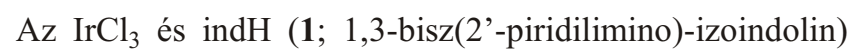
reakciójában képződő katalizátor aktivitását és stabilitását mutatja a 2. ábra, mely szerint a komplex 20 napon keresztül $100 \mathrm{~mL} /$ perc sebességü $\mathrm{H}_{2} / \mathrm{CO}_{2}$ gázfejlesztést tett lehetővé (folyamatos $\mathrm{HCO}_{2} \mathrm{H}$ betáplálással). Ez idő alatt a gázelegy közvetlen felhasználásával egy hidrogén üzemanyagcella feszültségét 7 V körüli értéken tudták tartani. A különösebb óvintézkedések nélkül tárolt szilárd katalizátor 370 nap után is változatlan aktivitást mutatott. Érdemes megjegyezni, hogy a katalizátor rosszul oldódik a vizes hangyasavban, lényegében tehát heterogén katalízis valósul meg.

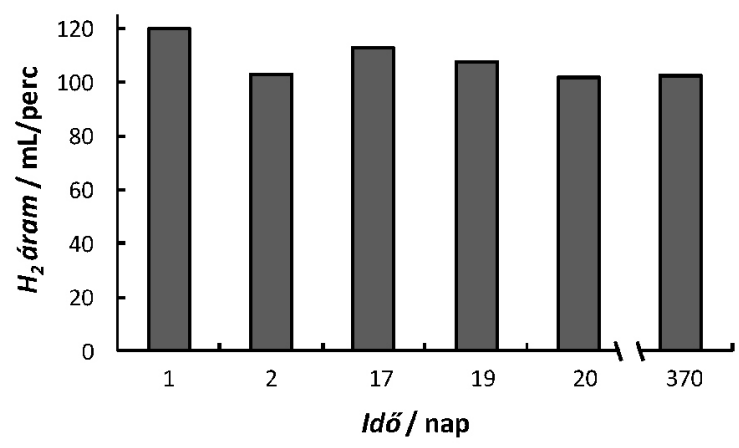

2. Ábra. Az Ir-indH katalizátor stabilitása hangyasav bontásában ${ }^{15}$. $[\mathrm{Ir}]=[\mathbf{1}]=9,987 \mathrm{mM} ;\left[\mathrm{HCO}_{2} \mathrm{H}\right]_{0}=3,50 \mathrm{M} ;\left[\mathrm{HCO}_{2} \mathrm{Na}\right]=0,40 \mathrm{M} ; T=100^{\circ} \mathrm{C}$.

Mint korábban említettük, a $\mathrm{CO}_{2}$ hidrogénezése hangyasavvá adalékanyagok nélkül csak lassan és csekély konverzióval megy végbe, ezért ez a kémiai folyamat $\mathrm{H}_{2}$ akkumulátorok kialakítására nem alkalmas. Nagyobb esélyt nyújt erre a formiát sók vizes oldatban végrehajtott dehidrogénezése, összekapcsolva a hidrogénkarbonát sók hidrogénezésével (4. egyenlet).

$$
\mathrm{HCO}_{2} \mathrm{Na}+\mathrm{H}_{2} \mathrm{O} \text { Ý } \mathrm{HCO}_{3} \mathrm{Na}+\mathrm{H}_{2}
$$

Oláh György és munkatársai Ru(II)-pincer komplexeket használtak erre a célra ${ }^{16}$. Ezek közül 3 és 4 (3. ábra) mind a $\mathrm{HCO}_{3} \mathrm{Na}$ hidrogénezésére, mind a $\mathrm{HCO}_{2} \mathrm{Na}\left(+\mathrm{H}_{2} \mathrm{O}\right)$ dehidrogénezésére alkalmasnak bizonyult tetrahidrofurán/víz elegyekben. A reakciók viszonylag lassan, de a katalizátor aktivitásának lényeges csökkenése nélkül mentek végbe; hat hidrogénezés/dehidrogénezés ciklus során az összesített katalitikus ciklusszám (TON = átalakított szubsztrátum anyagmennyisége/katalizátor anyagmennyisége) 11500 volt. Elvileg az ilyen tipusú Ru(II)-komplexek lehetőséget adnak hidrogén akkumulátorok megalkotására, azonban az említett közleményben ${ }^{16}$ erről a szerzők nem számolnak be.

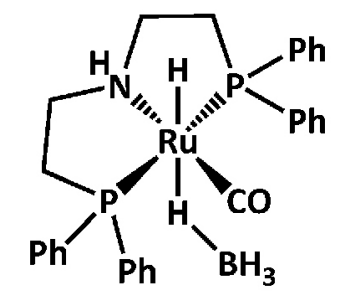

3

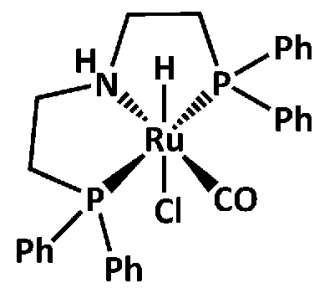

4
3. Ábra. Ru-pincer katalizátorok $\mathrm{H}_{2}$ fejlesztéséhez víz/tetrahidrofurán elegyekben oldott Na-formiátból ${ }^{16}$. 
3. Hangyasav katalitikus dehidrogénezése és hidrogénkarbonát/formiát alapú $H_{2}$ akkumulátorok saját eredmények

\subsection{Hangyasav katalitikus dehidrogénezése}

A hangyasav homogén katalitikus dehidrogénezésére számos katalizátor alkalmas, ezek közül néhányat a 4. ábrán mutatunk be. Igen nagy katalitikus aktivitást észleltek ródium ${ }^{17,18}$, ruténium $^{19}$ és iridium ${ }^{20}$ komplexekkel, de különféle vas ${ }^{21}$ és nikkel $^{22}$ komplexeket is aktívnak találtak. Himeda és munkatársai részletesen vizsgálták különféle hidroxibipiridin és hidroxibipirimidin ligandumok $\operatorname{Ir}(\mathrm{I})$ komplexeit, melyek kiváló katalizátornak bizonyultak. Így pl. [Cp* $\left.\operatorname{Ir}\left(\mathrm{H}_{2} \mathrm{O}\right) \mathrm{L}\right], 5$ katalizátor alkalmazásával $\left(\mathrm{Cp}^{*}=\right.$ pentametilciklopentadienil, $\mathrm{L}=6$-(4,5-dihydro-1H-imidazol-2-il) pirimidin-2,4-diol) rendkívül gyors $\mathrm{H}_{2}$ fejlődést tapasztaltak, a katalitikus frekvencia, TOF $=$ TON/idő $=322000 \mathrm{~h}^{-1}$-nek adódott ${ }^{23}$. Li és munkatársai a $\left[\mathrm{Cp}^{*} \operatorname{IrCl}(2,2\right.$ '-bi-1,4,5,6-tetrahidropirimidin)]Cl, 6 katalizátor esetében tapasztalták az eddig ismert legnagyobb katalitikus aktivitást ebben a reakcióban $\left(\mathrm{TOF}=486500 \mathrm{~h}^{-1}\right)$ és az elért katalitikus ciklusszám TON = 2400000 volt $^{24}$.

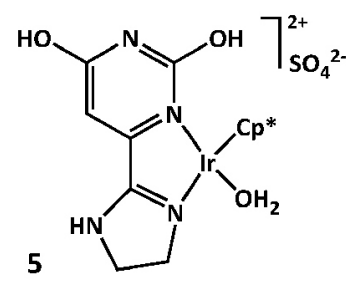<smiles></smiles>

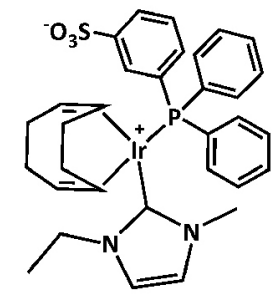

9

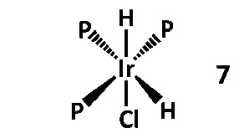<smiles>O=P(O)(O)c1cccc(S(=O)(=O)O)c1</smiles>

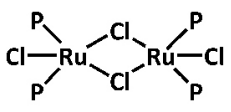

8
4. Ábra. Néhány nagy aktivitású katalizátor hangyasav bontásához.

Ir(I)-tercier foszfin komplexeket elsőként Coffey használt hangyasav bontásának katalízisére 1967-ben. [ $\left.\mathrm{IrH}_{3}\left(\mathrm{PPh}_{3}\right)_{3}\right]$ alkalmazásával TOF $=8890 \quad \mathrm{~h}^{-1}, \quad\left[\mathrm{IrH}_{2} \mathrm{Cl}\left(\mathrm{PPh}_{3}\right)_{3}\right]$ használatával pedig TOF $=1187 \mathrm{~h}^{-1}$ katalitikus aktivitást tapasztalt ${ }^{25}$

A vizes közegű fémorganikus katalízis tanulmányozása során azt találtuk, hogy $\mathrm{IrCl}_{3} \times 3 \mathrm{H}_{2} \mathrm{O}$ és monoszulfonált trifenilfoszfin Na-só (3-difenilfoszfino-benzolszulfonsav Na-só, $m$ tppms-Na) etanolos oldatát refluxálva abból fehér csapadékként kiválik a cisz-mer-[ $\left.\mathrm{IrH}_{2} \mathrm{Cl}(m \text { tppms-Na) })_{3}\right]$ komplex (4. ábra, 7) ${ }^{26}$ A vegyületet elemanalízissel, infravörös valamint ${ }^{1} \mathrm{H},{ }^{31} \mathrm{P}$ és ${ }^{13} \mathrm{C}$ NMR spektroszkópiával és ESI-MS spektrometriával jellemeztük.

A komplex jól oldódik vízben és vizes hangyasav oldatokban. A hangyasav bontás sebességét atmoszférikus nyomáson, $30-70{ }^{\circ} \mathrm{C}$ hömérséklet tartományban vizsgáltuk $(5 \text {. ábra })^{26}$.

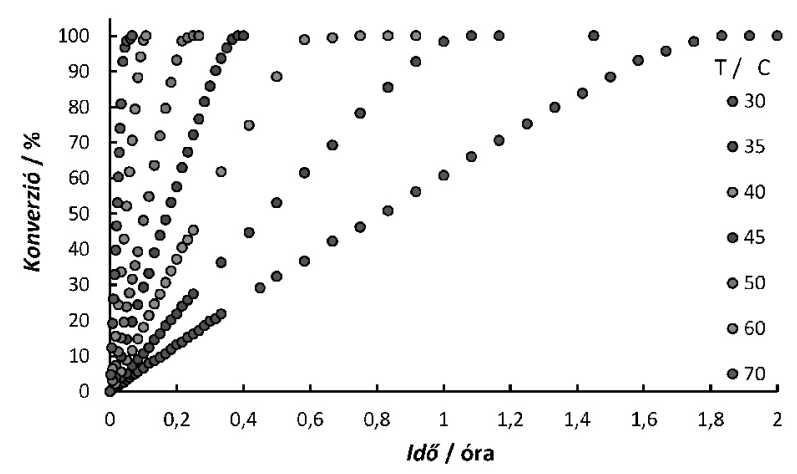

5. Ábra. Hidrogén fejlesztés hangyasav cisz-mer-[ $\left.\mathrm{IrH}_{2} \mathrm{Cl}(m \text { tppms-Na) })_{3}\right]$ katalizálta bontásával - a hömérséklet hatása. $\mathrm{n}(7)=4.9 \times 10^{-6} \mathrm{~mol}$; $\mathrm{n}\left(\mathrm{HCO}_{2} \mathrm{H}\right)=3.58 \times 10^{-3} \mathrm{~mol} ; \mathrm{n}\left(\mathrm{HCO}_{2} \mathrm{Na}\right)=4.9 \times 10^{-4} \mathrm{~mol} ; V=5,0 \mathrm{~mL}$.

A katalitikus aktivitás a hőmérséklet növelésével exponenciálisan nött, $70^{\circ} \mathrm{C}$-on $\mathrm{TOF}=17813 \mathrm{~h}^{-1}$ katalitikus frekvenciát határoztunk meg. A reakció sebessége éles maximumot mutatott $\mathrm{pH}=3,75-$ nél; ez az érték megfelel a hangyasav $\mathrm{pK}_{\mathrm{a}}$ értékének a reakció körülményei között. Nagyobb hangyasav mennyiségek bontásakor a reakciót egy $100 \mathrm{~mL}$ térfogatú Parr-reaktorban vizsgáltuk, és a nyomás időbeli növekedését követtük (a reakció lejátszódását követően nagy hatékonyságú folyadékkromatográfia alkalmazásával az esetleg maradó $\mathrm{HCO}_{2} \mathrm{H}$ koncentrációt is meghatároztuk). $\quad 100{ }^{\circ} \mathrm{C}$ hőmérsékleten TOF $=298000 \mathrm{~h}^{-1}$ katalitikus frekvencia értéket határoztunk meg, ami szerint a cisz-mer-[ $\left.\mathrm{IrH}_{2} \mathrm{Cl}(m \text { tppms-Na })_{3}\right]$ az oldható fémkomplexek között a harmadik legnagyobb aktivitású ismert katalizátor $\mathrm{H}_{2}$ fejlesztéséhez hangyasav bontása révén. Kiváló a vegyület stabilitása is: egy 40 órás kísérletben $11{ }^{\circ} \mathrm{C}$ hőmérsékleten a katalitikus ciklusszám TON $=674000$ volt $^{26}$. A katalizátor elsősorban aktivitása és stabilitása miatt érdemel figyelmet, de lényeges szempont az előállítás egyszerüsége is.

\subsection{Formiát/hidrogénkarbonát alapú $\mathrm{H}_{2}$-akkumulátorok}

A szulfonált trifenilfoszfint tartalmazó $\left[\left\{\mathrm{RuCl}_{2}(m \text { tppms-Na })_{2}\right\}_{2}\right]$ az egyik legrégebben ismert katalizátor a vizes közegü fémorganikus katalízisben ${ }^{27}$. Egyebek mellett felhasználást nyert $\mathrm{C}=\mathrm{C}$ és $\mathrm{C}=\mathrm{O}$ telítetlen vegyületek hidrogénezésében, vizes közegben oldott formiát sókról történő hidrogén-átvitel révén ${ }^{28}$. Korábbi munkánk során kimutattuk, hogy ez a vegyület már viszonylag enyhe körülmények között is aktívan katalizálja a hidrogénkarbonát sók hidrogénezését formiáttá (4. egyenlet, az alsó nyíl irányában $)^{29}$. Azt is tapasztaltuk, hogy zárt reaktorokban a hidrogénezési folyamat nem játszódott le $100 \%$ konverzióval, ami arra utalt, hogy a képződő formiát bomlásával (dehidrogéneződés) is számolni kell. Az a kedvezö helyzet áll tehát elö, hogy ugyanaz a vegyület, a [ $\left.\left\{\mathrm{RuCl}_{2}(m \text { tppms-Na })_{2}\right\}_{2}\right](\mathbf{8})$ mindkét irányban katalizálja a (4) folyamatot. A reakció termodinamikai paraméterei (egyensúlyi helyzete) valamint a hidrogénezés ill. dehidrogénezés sebessége optimális esetben lehetővé tehetik egy a gyakorlatban is müködő $\mathrm{H}_{2}$-akkumulátor összeállítását. Az akkumulátorban lejátszódó ciklikus folyamatok vázlatát a 6 . ábra mutatja. 


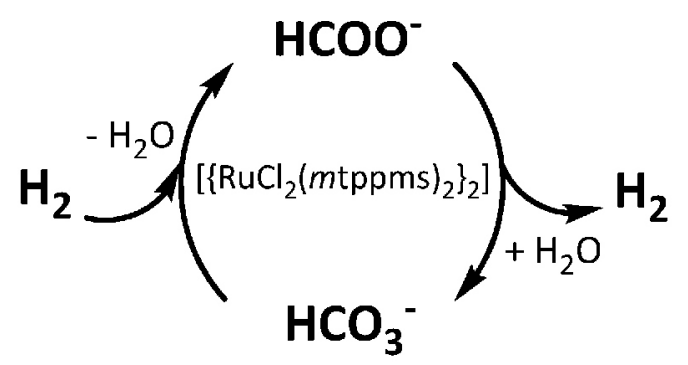

6. Ábra. $\mathrm{HCO}_{3}{ }^{-}$hidrogénezés/ $\mathrm{HCO}_{2}{ }^{-}$dehidrogénezés ciklus $\left[\left\{\mathrm{RuCl}_{2}(m \text { tppms-Na })_{2}\right\}_{2}\right], \mathbf{8}$ katalizátorral.

A $\mathrm{H}_{2}$-akkumulátorban lejátszódó folyamatokat modellrendszeren, nagynyomású zafír NMR-csőben, ${ }^{13} \mathrm{C}$ NMR spektroszkópia segítségével vizsgáltuk, $\mathrm{H}^{13} \mathrm{CO}_{3} \mathrm{Na}$ alkalmazásával ${ }^{30}$. Az eredményeket a 7 . ábra mutatja.

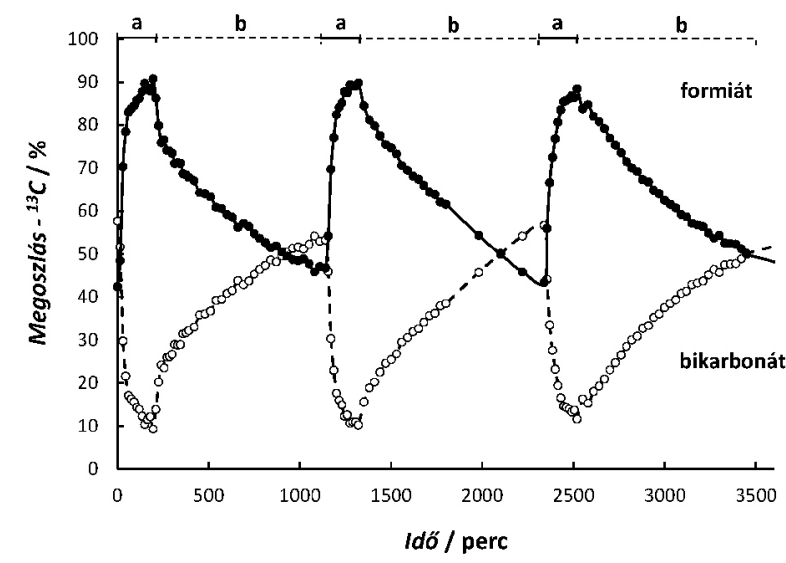

7. Ábra. $\mathrm{HCO}_{3}{ }^{-}$hidrogénezés $(\mathbf{a}) / \mathrm{HCO}_{2}{ }^{-}$dehidrogénezés (b) ciklusok követése ${ }^{13} \mathrm{C}$ NMR spektroszkópiával ${ }^{30}$. a: töltés $P\left(\mathrm{H}_{2}\right)=100$ bar; $\mathbf{b}$ : kisütés $P\left(\mathrm{H}_{2}\right)=1$ bar. $[\mathrm{Ru}]=10 \mathrm{mM} ;[\mathrm{m}$ tppms $]=42,5 \mathrm{mM} ;\left[\mathrm{H}^{13} \mathrm{CO}_{3} \mathrm{Na}\right]=257$ $\mathrm{mM} ; T=83^{\circ} \mathrm{C}, V\left(\mathrm{D}_{2} \mathrm{O}\right)=2,0 \mathrm{~mL}$.

A ciklust a hidrogénkarbonát hidrogénezésével indítottuk, melynek vizes oldatát $83^{\circ} \mathrm{C}$ hőmérsékleten 100 bar $\mathrm{H}_{2}$ nyomás alá helyeztük. Kezdetben a ${ }^{13} \mathrm{C}$ izotóp kizárólag $\mathrm{H}^{13} \mathrm{CO}_{3}^{-}$ionként volt jelen, azonban 200 perc alatt a hidrogénkarbonát 90\%-a átalakult formiáttá (hidrogénezés), amit az NMR jel egyértelmüen mutatott. Ekkor a $\mathrm{H}_{2}$-nyomást a csőben 1 bar-ra csökkentettük, a csövet ismét lezártuk és továbbra is $83^{\circ} \mathrm{C}$ hőmérsékleten tartottuk. Ezen a nyomáson és hőmérsékleten megindult a formiát bomlása (dehidrogénezés), ami 1000 perc alatt mintegy 50\%-ban ment végbe. A hidrogénezés/ dehidrogénezés ciklust még kétszer megismételtük (7. ábra). Ez a rendszer volt az irodalomban elsőként leírt, adalékanyagot (bázist) nem alkalmazó, kizárólag szervetlen sók reakciójára épülő, és oldószerként egyedül vizet tartalmazó $\mathrm{H}_{2}$-akkumulátor. A további munkához lényeges bátorításként ez a kísérlet azt is egyértelműen megmutatta, hogy a hidrogénkarbonátformiát- $\mathrm{H}_{2}-\mathrm{H}_{2} \mathrm{O}$ rendszerben az egyensúly helyzete kellően érzékeny a hidrogén nyomására a technikailag ésszerü nyomások tartományában. Ez igen lényeges különbség a hangyasav bontásával összehasonlítva, amikor is a (2) folyamat lényegében egyirányúnak tekinthető és rendkivül nagy $\mathrm{H}_{2}$ nyomás alkalmazása sem vezet számottevő konverzióval $\mathrm{HCO}_{2} \mathrm{H}$ képződéshez ${ }^{20}$.

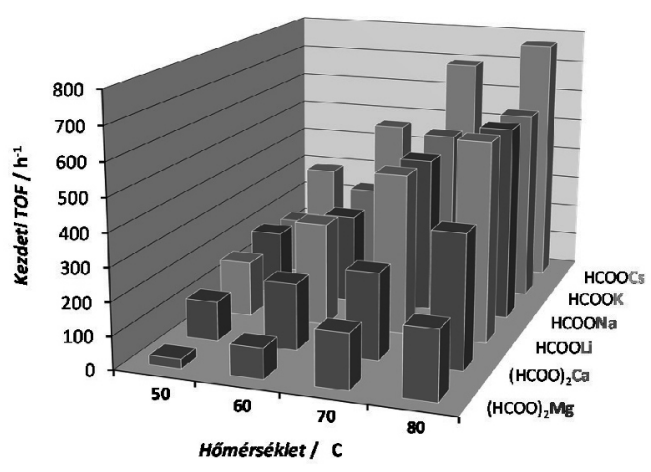

8. Ábra. Különféle formiát sók dehidrogénezésének sebessége a hömérséklet függvényében ${ }^{31}[\mathrm{Ru}]=2 \mathrm{mM} ;[m$ tppms $]=8 \mathrm{mM} ;\left[\mathrm{HCO}_{2}{ }^{-}\right]=$ $240 \mathrm{mM} ; V\left(\mathrm{H}_{2} \mathrm{O}\right)=5,5 \mathrm{~mL}$.

Ugyancsak a $\left[\left\{\mathrm{RuCl}_{2}(m \text { tppms-Na })_{2}\right\}_{2}\right]$ katalizátorral megvizsgáltuk különböző formiát sók dehidrogénezésének sebességét ill. azok hőmérsékletfüggését ${ }^{31}$. Azt tapasztaltuk, hogy míg a Li-, Na- és $\mathrm{K}$-formiát az $50-80^{\circ} \mathrm{C}$ hömérséklet tartományban összevethető sebességgel dehidrogénezhető, addig a Cs-formiát dehidrogénezésének sebessége mintegy 35-40\%-kal nagyobb (8. ábra). Minthogy oldékonysága is igen nagy (678 g/1000 g víz), ezért további kísérleteink során Cs-formiátot alkalmaztunk munkaanyagként.

A vizes közegü fémorganikus katalízis kutatások keretében széleskörüen vizsgáljuk vízoldható $N$-heterociklusos karbén ligandumú fémkomplexek alkalmazását különböző folyamatok (hidrogénezés, hidrodehalogénezés, redoxi izomerizáció, stb.) katalizátoraiként ${ }^{32,33}$.

Azt találtuk, hogy az $[\operatorname{Ir}(\operatorname{cod})(\mathrm{emim})(m$ tppms $)], 9$ (4. ábra; $\operatorname{cod}=1,5$-ciklooktadién, emim $=1$-etil-3-metilimidazol-2ilidén) kiemelkedően nagy sebességgel katalizálja mind a $\mathrm{HCO}_{3} \mathrm{Na}$ hidrogénezését, mind a $\mathrm{HCO}_{2} \mathrm{Na}\left(+\mathrm{H}_{2} \mathrm{O}\right)$ dehidrogénezését (9. ábra) ${ }^{34}$. Amint a 9. ábrán látható, $\mathrm{S} / \mathrm{C}=$ 10000 arány mellett, $80^{\circ} \mathrm{C}$ hőmérsékleten 20 perc alatt közel $600 \mathrm{~mL} \mathrm{H}$ fejlődött azaz a rendszer jelentős gázáramok létrehozására is alkalmas.

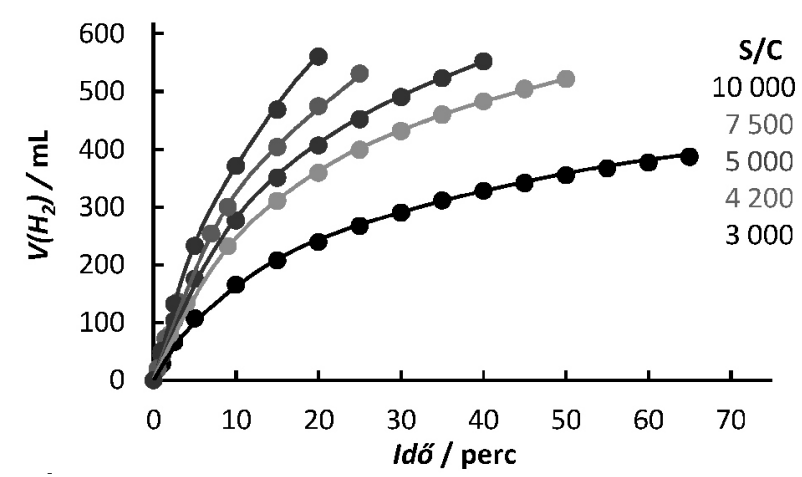

9. Ábra. Hidrogén fejlődés különböző $\left[\mathrm{HCO}_{2}{ }^{-}\right] /[\mathrm{Ir}](\mathrm{S} / \mathrm{C})$ értékeknél ${ }^{34} 9$ katalizátorral. [9] $=0,5 \mathrm{mM} ;[\mathrm{m}$ tppts-Na $]=1,0 \mathrm{mM} ; V\left(\mathrm{H}_{2} \mathrm{O}\right)=10,0 \mathrm{~mL}$; $T=80^{\circ} \mathrm{C} ; P($ total $)=1$ bar.

Ugyanakkor a $\mathrm{HCO}_{2} \mathrm{Cs}$ jó oldékonysága olyan reakcióelegyek alkalmazását is lehetővé teszi, melyben a szubsztrátum/katalizátor $(\mathrm{S} / \mathrm{C})$ arány akár 20000 is lehet. Itt jegyezzük meg, hogy szemben a hangyasav bontásával, 
amikor is $\mathrm{H}_{2}$ és $\mathrm{CO}_{2}$ 1:1 arányú elegye képződik, a vizes formiát oldatokból kizárólag $\mathrm{H}_{2}$ gázt nyerünk, ami előnyös a tüzelőanyag elemekben történő felhasználáshoz.

Ez esetben is elvégeztük a hidrogénezés és dehidrogénezés vizsgálatát ${ }^{13} \mathrm{C}$ NMR spektroszkópiával, az előzőekben ismertetett módon. Az eredmények azt mutatták, hogy 9 alkalmazásakor mindkét irányú folyamat rendkivül gyors (10. ábra). Egy hidrogénezési/dehidrogénezési ciklus teljes időigénye mindössze 60 perc volt, szemben a $\left[\left\{\mathrm{RuCl}_{2}(m \text { tppms-Na })_{2}\right\}_{2}\right]$ katalizátor esetével, amikor a teljes ciklus 1200 percet igényelt. A nagy aktivitás nagy stabilitással is párosul: amikor egy lezárt NMR csőben $\mathrm{H}_{2}$ alatt tárolt reakcióelegyet 71 nap múlva ismét megvizsgáltunk, a hidrogénezési, dehidrogénezési ciklusok ugyanolyan sebességgel játszódtak le, mint a reakcióelegy összeállítását követően az első ciklusok.

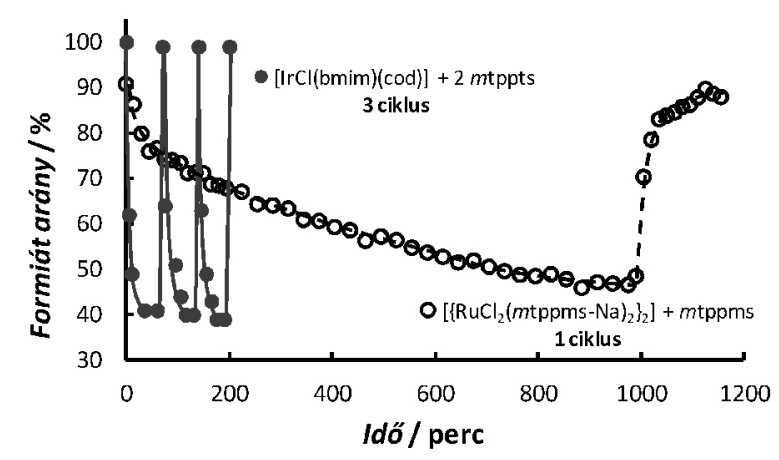

10. Ábra. Ir (9) és Ru (8) katalizátorok aktivitásának összehasonlítása ${ }^{13} \mathrm{C}$ NMR spektroszkópia segítségével ${ }^{34}$. [Ir] $=10 \mathrm{mM},[\mathrm{mtppts}]=20 \mathrm{mM}$; $[\mathrm{Ru}]=10 \mathrm{mM},[m \mathrm{tppms}]=42.5 \mathrm{mM} ;\left[\mathrm{H}^{13} \mathrm{CO}_{2} \mathrm{Na}\right]=257 \mathrm{mM} ; V\left(\mathrm{H}_{2} \mathrm{O}\right)=0,5$ $\mathrm{mL} ; \mathrm{T}=80^{\circ} \mathrm{C}$.

Felvetődik a kérdés, hogy gyakorlati alkalmazás céljára homogén katalitikus rendszerek egyáltalán szóba jönnek-e. Ilyenkor ugyanis a katalizátor és a reakcióelegy többi alkotója (hidrogénkarbonát, formiát, $\mathrm{H}_{2}, \mathrm{H}_{2} \mathrm{O}$ ) folyamatosan egy oldatban vannak és ez lehetőséget ad arra, hogy a hidrogénezés vagy dehidrogénezés szándékunk ellenére is lejátszódjon. Az akkumulátor müködésének szabályozásában -a nyomás mellett- fontos szerepe van a hőmérsékletnek. Egyrészt elönyös az, hogy közönséges hőmérsékleteken a formiát dehidrogénezés sebessége elenyésző. Másrészt viszont, amikor jelentős mennyiségü hidrogénre van szükség, akkor a reakcióelegyet megfelelő hőmérsékletre kell melegíteni. Nagy oldattérfogatok esetén sem a felfütés, sem a leálláskor szükséges hütés nem végezhető el gyorsan. Ezért az utóbbi időben az $[\operatorname{Ir}(\operatorname{cod})(\mathrm{emim})(m$ tppms $)], 9$ komplexszel katalizált folyamatot áramlásos rendszerben vizsgáljuk. A reakcióelegyet fö tömegét (a benne oldott katalizátorral) egy termosztált tartályban $25,0^{\circ} \mathrm{C}$ hömérsékleten tartjuk, miközben egy kis részét folyamatosan átvezetjük egy $100^{\circ} \mathrm{C}$ hőmérsékletre fütött csőreaktoron, majd vissza a tartályba. A reaktorból kilépő reakcióelegy lényegében szobahőmérsékletre hül mire a tartályba visszaér (léghütés). A tartály termosztálása elsősorban azért szükséges, mert a fejlődő $\mathrm{H}_{2}$ gáz térfogatát egy kapcsolt gázbürettával folyamatosan mérjük, ami állandó hőmérsékletet igényel. Egy ilyen gázfejlődési görbét mutat a 11. ábra. Eredményeink azt mutatják, hogy a tartály és a reaktor térfogatának és az áramlási sebességnek a megválasztásával elérhető, hogy kellő mennyiségű $\mathrm{H}_{2}$ fejlődjön anélkül, hogy a tartályban lévő reakcióelegy hőmérséklete lényegesen szobahőmérséklet fölé emelkedne.

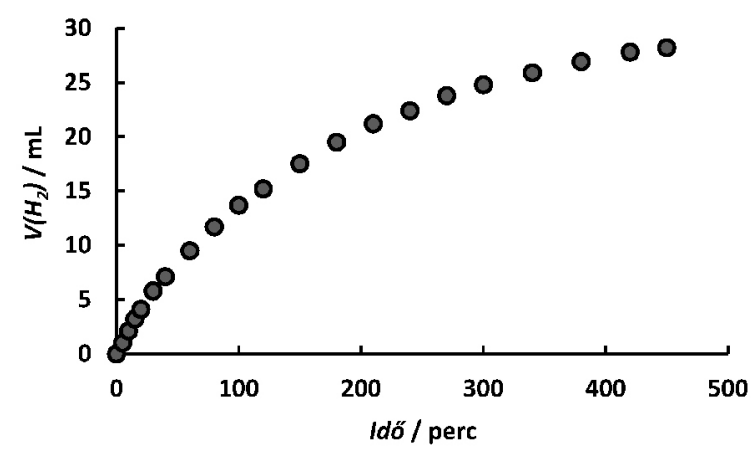

11. Ábra. Gázfejlődési görbe áramlásos reaktor alkalmazásával $[9]=0,033 \mathrm{mM} ;[\mathrm{mtppts}]=0,066 \mathrm{mM} ;\left[\mathrm{HCO}_{2} \mathrm{Cs}\right]=13,2 \mathrm{mM} ; V\left(\mathrm{H}_{2} \mathrm{O}\right)=25,0$ $\mathrm{mL} ; T=100^{\circ} \mathrm{C}$; áramlási sebesség $=2 \mathrm{~mL} /$ perc

\section{4. Összefoglalás}

Hidrogén kémiai tárolására alkalmas rendszereket vizsgáltunk. Megállapítottuk, hogy az egyszerüen szintetizálható cisz-mer-[ $\left.\mathrm{IrH}_{2} \mathrm{Cl}(m \text { tppms-Na) })_{3}\right], 7$ rendkivül nagy katalitikus aktivitással bontja a hangyasavat $\mathrm{H}_{2}$-re és $\mathrm{CO}_{2}$-re (katalitikus frekvencia $\left.298000 \mathrm{~h}^{-1}\right)$. Az adott reakcióelegyben a vegyület kémiai stabilitása is nagy: 40 óra alatt $115^{\circ} \mathrm{C}$ hömérsékleten a katalitikus ciklusszám $674 \quad 000 \quad$ volt. A formiát-hidrogénkarbonát- $\mathrm{H}_{2}-\mathrm{H}_{2} \mathrm{O}$ rendszert alkalmasnak találtuk gyakorlatban is megvalósítható $\mathrm{H}_{2}$-akkumulátorok alapjául. Az akkumulátorban lejátszódó hidrogénezési és dehidrogénezési folyamatot mind az $\left[\left\{\mathrm{RuCl}_{2}(m \text { tppms-Na })_{2}\right\}_{2}\right]$, 8 mind az $[\operatorname{Ir}(\operatorname{cod})(\mathrm{emim})(m$ tppms $)], 9$ komplex hatékonyan katalizálja; az utóbbi katalizátor 20-szor nagyobb sebességü hidrogénezést és dehidrogénezést tett lehetővé, mint a Ru-komplex. Az iridium-alapú katalizátor kiemelkedő kémiai stabilitást mutatott. Áramlásos reaktorban a hidrogén fejlődés sebessége a reaktor térfogatának és hőmérsékletének valamint az áramlási sebességnek a megválasztásával úgy szabályozható, hogy a reakcióelegy fö tömege nem melegszik fel jelentősen.

\section{Köszönetnyilvánítás}

A szerzők köszönetet mondanak Szabolcsi Roland, Ölveti Gábor és Kovács Henrietta közreműködéséért a kísérleti munka egyes részeiben. A kutatás a GINOP-2.3.2-15-2016-00008 számú projekt keretében, az Európai Unió támogatásával, az Európai Regionális Fejlesztési Alap társfinanszírozásával valósult meg. A kutatást a Nemzeti Kutatási, Fejlesztési és Innovációs Hivatal támogatta (NKFI-1 PD115535). 


\section{Hivatkozások}

1. A Mauna Loa Observatory adatsora; https://www.esrl.noaa.gov/gmd/obop/mlo/

2. Nikolaidis, P.; Poullikkas, A. Renew. Sustain. Energy Rev. 2017, 67, 597-611;

3. Olah, G. A.; Prakash, G. K. S.; Goeppert, A. J. Am. Chem. Soc. 2011, 133, 12881-12898; https://doi.org/10.1021/ja202642y

4. Horváth, I. T.; Mehdi, H.; Fábos, V.; Boda, L.; Mika, L. T. Green Chemistry 2008, 10, 238-242; https://doi.org/10.1039/B712863K

5. F. Ortenzi, G. Pede, A. S. Ramadhas, in Alternative Fuels for Transportation, ed. A. S. Ramadhas, CRC Press, 2011; ISBN 9781439819579

6. a. Olah, G. A.; Goeppert, A.; Prakash, G. K. S. Beyond Oil and Gas: The Methanol Economy, 2. kiadás, Wiley-VCH, Weinheim, Németország, 2009. /b. Oláh György - Goeppert, Alain - Prakash, G. K. Surya: Köolaj és földgáz után: a metanolgazdaság. Better, Budapest, 2008. 368. o; ISBN 978-963-86233-5-5.

7. Olah, G. A.; Prakash, G. K. S. Efficient and Selective Chemical Recycling of Carbon Dioxide to Methanol, Dimethyl Ether and Derived Products. U.S.Patent 7608 743, 2009.

8. Sordakis, K.; Tang, C.; Vogt, L.K.; Junge, H.; Dyson, P.J.; Beller, M.; Laurenczy, G. Chem. Rev. 2017, accepted; https://doi.org/10.1021/acs.chemrev.7b00182

9. http://www.chemicals-technology.com/projects/george-olah -renewable-methanol-plant-iceland/

10. Loges, B.; Boddien, A.; Junge, H.; Beller, M. Angew. Chem. Int. Ed. 2008, 47, 3962-3965; https://doi.org/10.1002/anie.200705972

11. Tanaka, R.; Yamashita, M.; Chung, L. W.; Morokuma, K.; Nozaki, K. Organometallics 2011, 30, 6742-6750; https://doi.org/10.1021/om2010172

12. Fellay, C.; Dyson, P.J., Laurenczy, G. Angew. Chem. Int. Ed. 2008, 47, 3966-3968; https://doi.org/10.1002/anie.200800320

13. Q. Liu, X. Yang, Y. Huang, S. Xu, X. Su, X. Pan, J. Xu, A. Wang, C. Liang, X. Wang, T. Zhang, Energy Environ. Sci. 2015, 8, 3204-3207; https://doi.org/10.1039/C5EE02506K

14. F. Wang, J. Xu, X. Shao, X. Su, Y. Huang, T. Zhang, ChemSusChem, 2016, 9, 246-251; https://doi.org/10.1002/cssc. 201501376

15. Czaun, M; Kothandaraman, J.; Goeppert, A.; Yang, B.; Greenberg, S.; May, R. B.; Olah, G. A.; Prakash, G. K. S. ACS Catalysis 2016, 6, 7475-7484; https://doi.org/10.1021/acscatal.6b01605

16. Kothandaraman, J.; Czaun, M.; Goeppert, A.; Haiges, R.; Jones, J.-P.; May, R. B.; Prakash, G. K. S.; Olah, G. A. ChemSusChem 2015, 8, 1442-1451; https://doi.org/10.1002/cssc. 201403458

17. Fukuzumi, S.; Kobayashi, T.; Suenobu, T. ChemSusChem 2008, 1, 827-834; https://doi.org/10.1002/cssc.200800147
18. Jószai, I.; Joó, F. J. Mol. Catal. A 2004, 224, 87-91; https://doi.org/10.1016/j.molcata.2004.08.045

19. Mellone, I.; Bertini, F.; Peruzzini, M.; Gonsalvi, L. Catal. Sci. Technol. 2016, 6, 6504-6512; https://doi.org/10.1039/C6CY01219A

20. Iguchi, M.; Himeda, Y.; Manaka, Y.; Kawanami, H. ChemSusChem 2016, 9, 2749-2753; https://doi.org/10.1002/cssc.201600697

21. Boddien, A.; Mellmann, D.; Gartner, F.; Jackstell, R.; Junge, H.; Dyson, P. J.; Laurenczy, G.; Ludwig, R.; Beller, M. Science 2011, 333, 1733-1736; https://doi.org/10.1126/science.1206613

22. Enthaler, S.; Brück, A.; Kammer, A.; Junge, H.; Irran, E.; Gülak, S. ChemCatChem 2015, 7, 65-69; https://doi.org/10.1002/cctc.201402716

23. Wang, W. H.; Ertem, M. Z.; Xu, S.; Onishi, N.; Manaka, Y.; Suna, Y.; Kambayashi, H.; Muckerman, J. T.; Fujita, E.; Himeda, Y. ACS Catal. 2015, 5, 5496-5504; https://doi.org/10.1021/acscatal.5b01090

24. Wang, Z.; Lu, S-M.; Li, J.; Wang, J.; Li, C. Chem. Eur. J. 2015, 21, 12592- 12595; https://doi.org/10.1002/chem.201502086

25. Coffey, R. S. Chem. Commun. 1967, 923; https://doi.org/10.1039/c1967000923a

26. Papp, G.; Ölveti, G.; Horváth, H.; Kathó, Á.; Joó, F. Dalton Trans. 2016, 45, 14516-14519; https://doi.org/10.1039/C6DT01695B

27. Tóth, Z.; Joó, F.; Beck, M. T. Inorg. Chim. Acta 1980, 42, 153-161; https://doi.org/10.1016/S0020-1693(00)88906-9

28. Bényei, A.; Joó, F. J. Mol. Catal. 1990, 58, 151-163; https://doi.org/10.1016/0304-5102(90)85035-G

29. Joó, F.; Laurenczy, G.; Nádasdi, L.; Elek, J. J. Chem. Soc. Chem. Commun. 1999, 971-972; http://dx.doi.org/10.1039/A902368B

30. Papp, G.; Csorba, J.; Laurenczy, G.; Joó, F. Angew. Chem. Int. Ed. 2011, 50, 10433-10435; https://doi.org/10.1002/anie.201104951

31. Papp, G.; Horváth, H.; Purgel, M.; Baranyi, A.; Laurenczy, G.; Joó F. 18th Int. Symp. Homogeneous Catalysis (ISHC-18), July 9-13, 2012, Toulouse, France, Book of Abstracts P-085.

32. Csabai, P.; Joó, F. Organometallics 2004, 23, 5640-5643; https://doi.org/10.1021/om049511a

33. Horváth, H.; Kathó, Á.; Udvardy, A.; Papp, G.; Szikszai, D.; Joó, F. Organometallics 2014, 33, 6330-6340; https://doi.org/10.1021/om5006148

34. Horváth, H.; Papp, G..; Szabolcsi, R.; Kathó, Á.; Joó, F. ChemSusChem 2015, 8, 3036-3038; https://doi.org/10.1002/cssc.201500808

35. Horváth, H; Papp, G.; Kovács, H.; Kathó, Á.; Joó F. 6th Conf. on Frontiers in Organic Synthesis Technology (FROST-6), October 18-20, 2017, Budapest, Hungary, P-32. Book of Abstracts, p. 83. https://doi.org/10.1039/c1967000923a 


\section{Storage of hydrogen in homogeneous catalytic chemical systems. A tribute to George Olah.}

Increase of the concentration of carbon dioxide in the atmosphere can be reduced by replacing fossil fuels with synthetic fuels produced on the expense of renewable energy, provided ultimately by the Sun. Available amounts of solar, wind and similar energies are fluctuating in time, depending on weather conditions, consequently the energy derived from such sources must be stored to allow use on demand.

George Olah was a pioneer and resolute proponent of the so-called methanol economy $y^{6,7}$. According to this concept -in addition to other uses- methanol is seen as the most important liquid fuel for transportation vehicles and local power plants, ideally via application of direct methanol fuel cells. When methanol is obtained by hydrogenation of $\mathrm{CO}_{2}$ (eq. 1) its oxidation merely gives back the amount of $\mathrm{CO}_{2}$ used for its synthesis, so the cycle is carbon neutral (with thermodynamic limitations). Although in the everyday practice methanol has not yet acquired the status of general purpose liquid fuel, its synthesis based on hydrogenation of atmospheric $\mathrm{CO}_{2}$ is practiced by Carbon Recycling International in the George Olah Renewable Methanol Plant at Reykjanes, Iceland ${ }^{9}$.

Hydrogen has also been suggested as general purpose energy carrier (hydrogen economy ${ }^{2}$ ), however, being a flammable gas at atmospheric pressure it requires special handling. Catalytic hydrogenation/dehydrogenation of suitable compounds as means of $\mathrm{H}_{2}$ storage has attracted much interest recently. Formic acid (FA) has emerged as one of the possible storage materials since its catalytic decomposition supplies $\mathrm{H}_{2}$ (+ equimolar amounts of $\mathrm{CO}_{2}$, eq. 2). Similarly, aqueous solutions of formate salts can be dehydrogenated to yield pure $\mathrm{H}_{2}$ and bicarbonates (eq. 4). $\mathrm{H}_{2}$ or $\mathrm{H}_{2}+\mathrm{CO}_{2}$ mixtures can be directly used in fuel cells for generation of electricity.

Olah and co-workers developed catalysts for both processes. For decomposition of formic acid, the Ir-complex obtained in reaction of $\mathrm{IrCl}_{3}$ and $\mathrm{IndH}$ (1, Fig. 1) proved to be a highly active and durable catalyst which showed unchanged activity even after 370 days (Fig. 2) ${ }^{15}$. Conversely, for dehydrogenation of Na-formate (in THF-water mixtures) $\mathrm{Ru}(\mathrm{II})$-pincer complexes, such as $\mathbf{3}$ (Fig 3) were synthetized ${ }^{16}$. Although the latter dehydrogenation reactions were relatively slow, 3 was capable of catalysis of bicarbonate hydrogenation, too, and this allowed construction of a dehydrogenation/hydrogenation cycle with the same catalyst for both half-reactions.
During our research on aqueous organometallic catalysis we have synthetized a number of water-soluble transition metal catalytsts for hydrogenations in aqueous systems or for hydrogen transfer from aqueous formates to $\mathrm{C}=\mathrm{C}$ and $\mathrm{C}=\mathrm{O}$ unsaturated compounds ${ }^{27,28}$. Several of these catalysts could be usefully applied for hydrogen storage and/or delivery, too.

One of the earliest examples of homogeneous catalytic decomposition of formic acid with the use of $\left[\mathrm{IrH}_{3}\left(\mathrm{PPh}_{3}\right)_{3}\right]$ and $\left[\mathrm{IrH}_{2} \mathrm{Cl}\left(\mathrm{PPh}_{3}\right)_{3}\right]$ catalysts was published by Coffey in $1967^{25}$ We have found that a similar, but water-soluble iridium(I) complex, cisz-mer-[ $\left.\mathrm{IrH}_{2} \mathrm{Cl}(m \text { tppms-Na) })_{3}\right], 7$ (Fig. 4) was outstandingly active in FA decomposition; in fact it showed the third highest activity $\left(\mathrm{TOF}=298000 \mathrm{~h}^{-1}\right)$ among the known homogeneous catalysts of this reaction ${ }^{26}$. High chemical stability of 7 is exemplified by the high turnover number $(\mathrm{TON}=674000)$ obtained in the presence of a large excess of formic acid.

With the purpose of hydrogen storage in chemical systems we investigated the catalytic activity of $\left[\left\{\mathrm{RuCl}_{2}(m \mathrm{tppms})_{2}\right\}_{2}\right], \mathbf{8}$ (Fig. 4) both in hydrogenation of Na-bicarbonate ${ }^{29}$ and in dehydrogenation of aqueous $\mathrm{Na}$-formate ${ }^{30}$. It was discovered that the two processes could be successfully coupled for construction of a hydrogen battery ${ }^{30}$. In such a device hydrogen uptake or delivery can be regulated merely by changing the $\mathrm{H}_{2}$ pressure. Charge/discharge cycles were followed by ${ }^{13} \mathrm{C}$ NMR spectroscopy (Fig. 7). Even more satisfyingly, the mixed-ligand $[\operatorname{Ir}(\operatorname{cod})(\mathrm{emim})(m$ tppms $)], \quad 9 \quad$ (Fig. 4), containing both a tertiary phosphine and an $\mathrm{N}$-heterocyclic carbene (NHC) ligand showed approximately 20 times higher catalytic activity, than $\mathbf{8}^{34}$. These chemical systems represent viable hydrogen batteries, since -in addition to the catalyst and $\mathrm{H}_{2}-$ they contain only an aqueous solution of inorganic salts and the catalysts are stable for long times under $\mathrm{H}_{2}$ pressure.

The rates of hydrogen uptake or evolution is dependent on the temperature. However, in case of large volumes of aqueous storage solutions it is inconvenient (in practice, impossible) to heat or cool the entire solution to obtain sufficient $\mathrm{H}_{2}$ flow or to stop the reaction, respectively. Recently we work on developing closed-loop flow systems $^{35}$, in which only a fraction of the total volume is heated in a flow-through reactor. In such a device the $\mathrm{H}_{2}$ delivery can be regulated by proper combination of appropriate temperatures and flow rates without warming up the entire storage solution. 